() 2018 - ISSN 1807-2577

\title{
Behavioral and clinical aspects associated with probable sleep bruxism in early childhood
}

\author{
Aspectos comportamentais e clínicos associados ao provável bruxismo do \\ sono na primeira infância
}

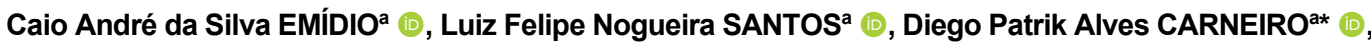
Patrícia Rafaela dos SANTOS ${ }^{\mathfrak{B}}$, Silvia Amélia Scudeler VEDOVELLOa ${ }^{\mathbb{B}}$, Heloisa Cristina VALDRIGHI ${ }^{a}$ (D)

aFHO/UNIARARAS - Fundação Hermínio Ometto, Departamento de Ortodontia, Araras, SP, Brasil

\begin{abstract}
How to cite: Emídio CAS, Santos LFN, Carneiro DPA, Santos PR, Vedovello SAS, Valdrighi HC. Behavioral and clinical aspects associated with probable sleep bruxism in early childhood. Rev Odontol UNESP. 2020;49:e20200044.

https://doi.org/10.1590/1807-2577.04420
\end{abstract}

\begin{abstract}
Resumo
Introdução: Embora muitos estudos estejam sendo realizados com o bruxismo do sono, a literatura aponta uma carência de estudos com qualidade metodológica em crianças. Objetivo: Avaliar os aspectos comportamentais e clínicos associados ao provável bruxismo do sono na primeira infância. Material e método: Estudo observacional transversal realizado com 371 crianças entre 4 e 6 anos de idade. Os pais responderam a um questionário com aspectos relacionados ao comportamento do sono de seus filhos. Entre as características clínicas, foram avaliados a presença de selamento labial, estalidos, marcas dos dentes na mucosa julgal e na lateral da língua. 0 desgaste dentário foi avaliado por meio dos critérios do índice de BEWE. Foram ajustados modelos de regressão logística simples, para cada variável independente, estimando-se os odds ratios brutos com os respectivos intervalos de $95 \%$ de confiança. As variáveis com $P<0.20$ nas análises individuais foram ajustadas em um modelo de regressão logística múltipla, permanecendo no modelo aquelas com $P \leq 0.05$. Resultado: $42.4 \%$ dos pais relataram que seus filhos rangiam os dentes enquanto dormiam. Crianças que apresentaram desgastes nos dentes, tinham 1.53 vezes mais chances de ranger os dentes. Não houve associação significativa com as demais variáveis analisadas $(P>0.05)$. Conclusão: Aspectos comportamentais não apresentaram associação com o provável bruxismo do sono. Entre as características clínicas avaliadas, o desgaste dentário apresentou associação, podendo ser um indicador para o provável bruxismo do sono na primeira infância.
\end{abstract}

Descritores: Bruxismo do sono; crianças; desgaste dentário.

\begin{abstract}
Introduction: Although many studies are being carried out with sleep bruxism, the literature points to a lack of studies with methodological quality in children. Objective: To evaluate the behavioral and clinical aspects associated with probable sleep bruxism in early childhood. Material and method: A cross-sectional observational study carried out with 371 children between 4 and 6 years of age. Parents answered a questionnaire with aspects related to their children's sleep behavior. Among the clinical characteristics, the presence of lip sealing, clicking, teeth marks on the jugal mucosa, and the side of the tongue was evaluated. Tooth wear was assessed using the BEWE index criteria. Simple logistic regression models were adjusted for each independent variable, estimating the gross odds ratios with the respective $95 \%$ confidence intervals. Variables with $P<0.20$ in the individual analyzes were adjusted in a multiple logistic regression model, with those with $P \leq 0.05$ remaining in the model. Result: $42.4 \%$ of parents reported that their children gritted their teeth while sleeping. Children who showed wear on their teeth were 1.53 times more likely to grind their teeth. There was no significant association with the other variables analyzed $(P>0.05)$. Conclusion: Behavioral aspects were not associated with probable sleep bruxism. Among the clinical characteristics evaluated, tooth wear showed an association, which may indicate the probable bruxism of sleep in early childhood.
\end{abstract}

Descriptors: Sleep bruxism; children; tooth wear. 


\section{INTRODUCTION}

Defined as the repetitive movement of the mandibular muscles, the bruxism is characterized by the grinding and/or clenching of the teeth, which can occur while the individual is awake, known as awake bruxism, or during sleep, known as sleep bruxism ${ }^{1}$. The etiology is complex and multifactorial2,3, including biological factors (neurotransmitters, sleep alarms), psychological (stress, anxiety, personality) and exogenous (nicotine, alcohol, drugs, medications) (4,5. $^{4}$

Different methods are used for the diagnosis; however, only the polysomnographic examination can confirm the presence of bruxism, this method is considered the gold standard6-8. Therefore, for conducting epidemiological studies with sleep bruxism in children, this method is not viable9. The American Academy of Sleep Medicine (AASM) considers that the reports of parents/caregivers or the self-report of teeth grinding, are quite reliable and sufficient for use in epidemiological studies,10-12. For this reason, the report of the parents/caregivers can be an essential complaint to the dental surgeon, so that he may, in due course, investigate further ${ }^{6,13}$.

Based on the literature, tooth wear seems to be a classic sign in confirmed cases of sleep bruxism, affecting mainly the incisal of anterior and occlusal of posterior teeth at different levels of severity. However, tooth wear in primary teeth is still much discussed since physiological wear is a common clinical situation $8,14,15$. Sleep bruxism can be considered multifactorial; the information such as location and conditions in which children sleep can explain the quality of sleep and, consequently, their parents/caregivers' observation of the habit of grinding their teeth $^{12}$. Based on this information, the study hypothesis was that clinical variables evaluated and those related to sleep behavior are associated with the report of teeth grinding. Therefore, this study aimed to evaluate the behavioral and clinical aspects associated with probable sleep bruxism in early childhood.

\section{MATERIAL AND METHOD}

The STROBE (Strengthening the Reporting of Observational Studies in Epidemiology) guidelines were followed for the preparation and guidance of this study. This study was approved by the Human Research Ethics Committee (CAAE 01797118.3.0000.5385). Parents/caregivers and their children were invited and informed about the objective of the study and guaranteed the confidentiality of the collected data; in addition, they were informed that participation was entirely voluntary. After agreeing to participate in the study, the parents/guardians signed the free and informed consent form, and the children, the free and informed consent form. Data collection took place between March and June 2018. The parents received a questionnaire before the start of clinical data collection. Dental clinical examinations were carried out with the children inside the school.

\section{Participants}

A cross-sectional study was carried out with children from 4 to 6 years old, in the primary dentition stage, of both sexes, enrolled in municipal schools, and who did not have physical/mental impairment that would hinder their participation, previously authorized by parents/caregivers and who agreed to participate. The minimum sample was calculated based on a previous study ${ }^{12}$, considering the prevalence of bruxism in the unexposed group of $22.3 \%$, test power of $80 \%$, confidence level of $95 \%$, and minimum odds ratio detectable of 2.0 , resulting in a minimum number of 350 participants. 


\section{Non-clinical Data Collection}

To assess the probable sleep bruxism, the parents/guardians responded if their children had gnashed their teeth during sleep in the past 30 days, causing the parents/caregivers to hear the noises ${ }^{12,16,17}$. Also, the parents/guardians answered questions related to their children's sleep behavior, about where their children slept, whether they were close to their parents' dormitory, whether their children slept with the door open or closed and whether they slept with lights on based on the American Academy of Sleep Medicine criteria (Figure 1) ${ }^{12}$.

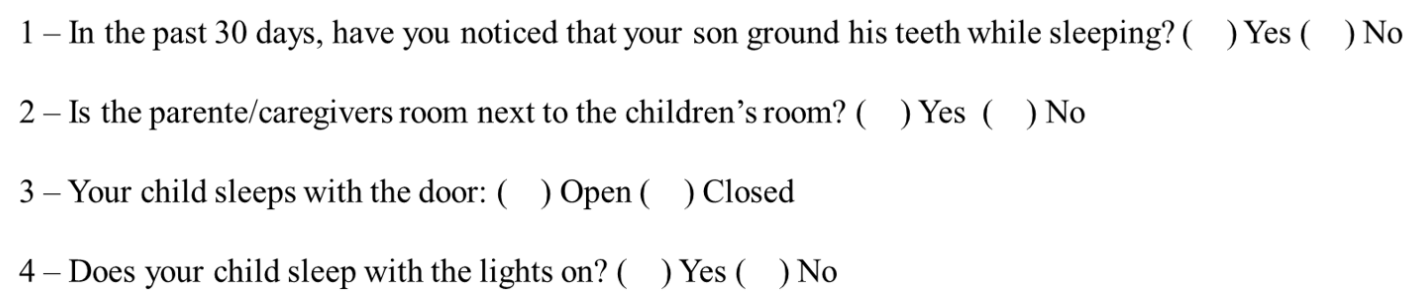

Figure 1. Questions used to collect non-clinical data.

A pilot study was carried out with 16 parents/caregivers to test the methodology. There was no need for adaptation, as the participants did not report any difficulty in understanding them. Pilot study participants were excluded and did not enter the main study.

\section{Clinical Data Collection}

Clinically, intra and extra oral exams were performed, which verified the presence of lip sealing, clicking, marks on the jugal and lateral mucosa of the tongue ${ }^{18}$. Lip sealing was assessed visually, observing whether or not the child's lips were sealed. The presence of marks on the jugal mucosa at the time the teeth touched and on the side of the tongue was assessed with the help of a wooden spatula. To assess the presence of clicking on the temporomandibular joint, the child was instructed to perform maximum opening, followed by closing ${ }^{18}$. For data analysis, the clinical characteristics evaluated were dichotomized in presence and absence.

Dental wear was assessed using the criteria recommended by the Basic Erosive Wear Examination (BEWE), where a scoring system is used to check the most severely affected surface of a sextant. The scores considered were: (0) no loss of surface; (1) initial loss of texture of the enamel surface; (2) less than $50 \%$ loss of surface or (3) loss of more than $50 \%$ of surface ${ }^{19}$. In the present study, tooth wear was classified based on the highest score present in the oral cavity, and dichotomized in the absence (scores 0 and 1 ) and presence (scores 2 and 3$)^{19}$.

\section{Statistical Analysis}

An absolute frequency distribution table of the studied independent variables was built. To perform the logistic regression analysis, the report of teeth grinding was considered as a dependent variable of this study (presence and absence); simple logistic regression analyzes were performed, estimating the gross odds ratio with the respective $95 \%$ confidence intervals. Variables with $P<0.20$ at each level were tested in multilevel multiple logistic regression models, with those with $P \leq 0.05$ remaining in the model, estimating the adjusted odds ratios with the respective $95 \%$ confidence intervals. 


\section{RESULT}

This study had the participation of 371 children, with an average age of 5.1 years (standard deviation of 0.3 years), being $51.5 \%$ girls and $71.4 \%$ white. According to the parents' report, $42.4 \%$ of the children gritted their teeth and, $93.5 \%$ had the dormitories close to their children's, $76.8 \%$ of the children slept with the door open, and $25.9 \%$ with lights on. $47.4 \%$ of the children showed wear, $15.9 \%$ absence of lip sealing, $11.6 \%$ presence of clicking, $54.4 \%$ presence of marks on the jugal mucosa, $14.8 \%$ presence of marks on the side of the tongue (Table 1) and $96.5 \%$ had at least one of the clinical characteristics evaluated.

Table 1. Questionnaire responses and clinical assessments

\begin{tabular}{ccc}
\hline Variable & Category & n (\%) \\
\hline \multirow{2}{*}{ Sex } & Male & $180(48.5 \%)$ \\
& Female & $191(51.5 \%)$ \\
Proximity to the child's room & Far & $24(6.5 \%)$ \\
& Near & $347(93.5 \%)$ \\
Room's door & Open & $285(76.8 \%)$ \\
& Closed & $86(23.2 \%)$ \\
Bedroom lights on & No & $275(74.1 \%)$ \\
& Yes & $96(25.9 \%)$ \\
Tooth wear & Absent & $195(52.6 \%)$ \\
& Present & $176(47.4 \%)$ \\
Lip sealing & Absent & $59(15.9 \%)$ \\
& Present & $312(84.1 \%)$ \\
Clicking & Absent & $328(88.4 \%)$ \\
& Present & $43(11.6 \%)$ \\
Marks on the jugal & Absent & $169(45.6 \%)$ \\
& Present & $202(54.4 \%)$ \\
Marks lateral mucosa of tongue & Absent & $316(85.2 \%)$ \\
& Present & $55(14.8 \%)$ \\
\hline
\end{tabular}

Table 2 shows the analysis of the associations of the variables analyzed with the presence of teeth grinding. It was possible to observe that children with the presence of tooth wear are 1.53 (1.00-2.31) times more likely to grind their teeth $(P<0.05)$. There was no significant association with the other variables analyzed $(P>0.05)$.

Table 2. Analysis of the associations of the variables analyzed with the presence of teeth grinding

\begin{tabular}{|c|c|c|c|c|c|c|c|}
\hline \multirow{2}{*}{ Variable } & \multirow{2}{*}{ Category } & \multicolumn{2}{|c|}{$\begin{array}{l}\text { Report of teeth } \\
\text { grinding }\end{array}$} & \multirow{2}{*}{$\begin{array}{l}\text { \$OR crude } \\
\text { ( }{ }^{\# C I)}\end{array}$} & \multirow{2}{*}{$\begin{array}{c}\text { p- } \\
\text { value }\end{array}$} & \multirow{2}{*}{$\begin{array}{c}\text { \$OR } \\
\text { ajusted } \\
\left({ }^{\#} \mathrm{CI}\right)\end{array}$} & \multirow{2}{*}{$\begin{array}{c}\text { p- } \\
\text { value }\end{array}$} \\
\hline & & $\begin{array}{c}\text { Absent } \\
\text { n (\%) } \\
\end{array}$ & $\begin{array}{c}\text { Present* } \\
\text { n (\%) } \\
\end{array}$ & & & & \\
\hline \multirow{2}{*}{ Sex } & Male & $\begin{array}{c}100 \\
(55.6 \%)\end{array}$ & $\begin{array}{c}80 \\
(44.4 \%)\end{array}$ & $\begin{array}{c}1.18 \\
(0.78-1.79)\end{array}$ & 0.4211 & & \\
\hline & Female & $\begin{array}{c}114 \\
(59.7 \%)\end{array}$ & $\begin{array}{c}77 \\
(40.3 \%)\end{array}$ & 1 & & & \\
\hline \multirow{2}{*}{$\begin{array}{l}\text { Proximity to the } \\
\text { child's room }\end{array}$} & Não Próximo & $\begin{array}{c}18 \\
(75.0 \%)\end{array}$ & $\begin{array}{c}6 \\
(25.0 \%)\end{array}$ & 1 & & & \\
\hline & Próximo & $\begin{array}{c}196 \\
(56.5 \%)\end{array}$ & $\begin{array}{c}151 \\
(43.5 \%)\end{array}$ & $\begin{array}{c}2.31 \\
(0.90-5.96)\end{array}$ & 0.0833 & & \\
\hline \multirow{2}{*}{ Room's door } & Open & $\begin{array}{c}170 \\
(59.6 \%)\end{array}$ & $\begin{array}{c}115 \\
(40.4 \%)\end{array}$ & 1 & & & \\
\hline & Closed & $\begin{array}{c}44 \\
(51.2 \%)\end{array}$ & $\begin{array}{c}42 \\
(48.8 \%) \\
\end{array}$ & $\begin{array}{c}1.41 \\
(0.87-2.29) \\
\end{array}$ & 0.1636 & & \\
\hline
\end{tabular}


Table 2. Continued...

\begin{tabular}{|c|c|c|c|c|c|c|c|}
\hline \multirow{3}{*}{ Variable } & \multirow{3}{*}{ Category } & \multicolumn{2}{|c|}{$\begin{array}{l}\text { Report of teeth } \\
\text { grinding }\end{array}$} & \multirow{3}{*}{$\begin{array}{l}\text { \$OR crude } \\
\text { (\#CI) }\end{array}$} & \multirow{3}{*}{$\begin{array}{c}\text { p- } \\
\text { value }\end{array}$} & \multirow{3}{*}{$\begin{array}{c}\text { \$OR } \\
\text { ajusted } \\
\text { (\#CI) }\end{array}$} & \multirow{3}{*}{$\begin{array}{c}\text { p- } \\
\text { value }\end{array}$} \\
\hline & & Absent & Present* & & & & \\
\hline & & n (\%) & n (\%) & & & & \\
\hline \multirow{2}{*}{ Bedroom lights on } & No & $\begin{array}{c}165 \\
(60.0 \%)\end{array}$ & $\begin{array}{c}110 \\
(40.0 \%)\end{array}$ & 1 & & & \\
\hline & Yes & $\begin{array}{c}49 \\
(51.0 \%)\end{array}$ & $\begin{array}{c}47 \\
(49.0 \%)\end{array}$ & $\begin{array}{c}1.44 \\
(0.90-2.30)\end{array}$ & 0.1270 & & \\
\hline \multirow[b]{2}{*}{ Tooth wear } & Absent & $\begin{array}{c}122 \\
(62.6 \%)\end{array}$ & $\begin{array}{c}73 \\
(37.4 \%)\end{array}$ & 1 & & 1 & \\
\hline & Present & $\begin{array}{c}92 \\
(52.3 \%)\end{array}$ & $\begin{array}{c}84 \\
(47.7 \%)\end{array}$ & $\begin{array}{c}1.53 \\
(1.00-2.31)\end{array}$ & 0.0456 & $\begin{array}{c}1.53 \\
(1.00- \\
2.31)\end{array}$ & 0.0456 \\
\hline \multirow{2}{*}{ Lip sealing } & Absent & $\begin{array}{c}36 \\
(61.0 \%)\end{array}$ & $\begin{array}{c}23 \\
(39.0 \%)\end{array}$ & 1 & & & \\
\hline & Present & $\begin{array}{c}178 \\
(57.1 \%)\end{array}$ & $\begin{array}{c}134 \\
(42.9 \%)\end{array}$ & $\begin{array}{c}1.18 \\
(0.67-2.08)\end{array}$ & 0.5721 & & \\
\hline \multirow{2}{*}{ Clicking } & Absent & $\begin{array}{c}186 \\
(56.7 \%)\end{array}$ & $\begin{array}{c}142 \\
(43.3 \%)\end{array}$ & $\begin{array}{c}1.42 \\
(0.73-2.77)\end{array}$ & 0.2958 & & \\
\hline & Present & $\begin{array}{c}28 \\
(65.1 \%)\end{array}$ & $\begin{array}{c}15 \\
(34.9 \%)\end{array}$ & 1 & & & \\
\hline \multirow{2}{*}{ Marks on the jugal } & Absent & $\begin{array}{c}92 \\
(54.4 \%)\end{array}$ & $\begin{array}{c}77 \\
(45.6 \%)\end{array}$ & $\begin{array}{c}1.28 \\
(0.84-1.93)\end{array}$ & 0.2477 & & \\
\hline & Present & $\begin{array}{c}122 \\
(60.4 \%)\end{array}$ & $\begin{array}{c}80 \\
(39.6 \%)\end{array}$ & 1 & & & \\
\hline \multirow{2}{*}{$\begin{array}{c}\text { Marks lateral mucosa } \\
\text { of tongue }\end{array}$} & Absent & $\begin{array}{c}187 \\
(59.2 \%)\end{array}$ & $\begin{array}{c}129 \\
(40.8 \%)\end{array}$ & 1 & & & \\
\hline & Present & $\begin{array}{c}27 \\
(49.1 \%)\end{array}$ & $\begin{array}{c}28 \\
(50.9 \%)\end{array}$ & $\begin{array}{c}1.50 \\
(0.85-2.67)\end{array}$ & 0.1641 & & \\
\hline
\end{tabular}

*Reference category for the outcome variable. ${ }^{\$}$ Odds ratio. $\# 95 \%$ confidence interval.

\section{DISCUSSION}

Based on previous studies, the prevalence of sleep bruxism in children varies from $3.5 \%$ to $40.6 \%{ }^{11,12}$. In our study, based on the parents' report, $42.4 \%$ of the children gnashed their teeth while sleeping. The findings' difference is due to the methodology used since the current systematic reviews highlight the lack of studies with adequate methodological quality for assessing bruxism and its associated factors in children ${ }^{9,17}$. Thus, the lack of standardization can produce different results, compromising comparisons between studies ${ }^{20}$.

The literature highlights that parents/caregivers' approach or self-report about grinding their teeth is the most used form ${ }^{9,14}$. Also, studies on sleep bruxism have found that tooth wear is a more common clinical consequence of bruxism of sleep $8,21,22$; however, in primary dentition, due to the lower degree of mineralization of the teeth, the presence of physiological wear is widespread $^{8}$. Therefore, the present study considers the presence of tooth wear, only in the most graves, to exclude physiological wear ${ }^{15}$. Our main finding was that children with severe dental wear were more likely to grind their teeth, a result that is contrary to the previous study, which does not consider only the most severe wear ${ }^{12}$.

Sleep is a complex physiological process influenced by intrinsic, biological properties, temperament, expectations, cultural norms and environmental conditions, such as light, is directly linked to the human clock and sleep pathophysiology ${ }^{16,23,24}$. Variables such as sleeping with lights on are significant since this habit can interfere with sleep quality ${ }^{12}$; however, our results did not find any association with the report of teeth grinding, and the literature has shown conflicting results about this association ${ }^{16,17}$. On the other hand, information about the proximity 
in which parents/caregivers sleep with their children, and whether the door remains open or closed could interfere with the observation of parents/caregivers; however, in the present study, there was no association between these variables, collaborating with the result of a previous study ${ }^{16}$. Despite the lack of association between sleep bruxism and the absence of lip sealing, there was no association between variables. Also, the literature recognizes that the presence of sleep bruxism is often associated with other respiratory disorders related to sleep, such as mouth breathing and sleep apnea ${ }^{7,18}$.

One of the biggest challenges for epidemiological studies on bruxism in children today is still the lack of standardization of the methodology ${ }^{9}$. Based on the literature, factors such as headache, muscle pain, low sleep quality, psychological factors, respiratory problems, and behavioral problems may be associated with sleep bruxism and may influence the development of comorbidities in the individual ${ }^{6,11,15,25-27}$. As with any pathology, it is essential to diagnose and intervene early, even with little concrete information, if identified, it is possible to intervene and consequently eliminate or reduce the impact on the child's life.

\section{CONCLUSION}

Among the clinical variables evaluated, there was severe tooth wear associated with the report of teeth grinding. Thus, severe dental wear associated with the parents' report can be considered an indicator of probable sleep bruxism in the early childhood of Brazilian children.

\section{REFERENCES}

1. Lobbezoo F, Ahlberg J, Glaros AG, Kato T, Koyano K, Lavigne GJ, et al. Bruxism defined and graded: an international consensus. J Oral Rehabil. 2013 Jan;40(1):2-4. http://dx.doi.org/10.1111/joor.12011. PMid:23121262.

2. Feu D, Catharino F, Quintão CCA, Almeida MAO. A systematic review of etiological and risk factors associated with bruxism. J Orthod. 2013 Jun;40(2):163-71. http://dx.doi.org/10.1179/1465313312Y.0000000021. PMid:23794697.

3. Klasser GD, Rei N, Lavigne GJ. Sleep bruxism etiology: the evolution of a changing paradigm. J Can Dent Assoc. 2015;81:f2. PMid:25633110.

4. Winocur E, Uziel N, Lisha T, Goldsmith C, Eli I. Self-reported bruxism: associations with perceived stress, motivation for control, dental anxiety and gagging. J Oral Rehabil. 2011 Jan;38(1):3-11. http://dx.doi.org/10.1111/j.1365-2842.2010.02118.x. PMid:20557433.

5. Martynowicz H, Smardz J, Wieczorek T, Mazur G, Poreba R, Skomro R, et al. The co-occurrence of sexsomnia, sleep bruxism and other sleep disorders. J Clin Med. 2018 Aug;7(9):233. http://dx.doi.org/10.3390/jcm7090233. PMid:30142877.

6. Carra MC, Bruni O, Huynh N. Topical review: sleep bruxism, headaches, and sleep-disordered breathing in children and adolescents. J Orofac Pain. 2012;26(4):267-76. PMid:23110266.

7. Castroflorio T, Bargellini A, Rossini G, Cugliari G, Rainoldi A, Deregibus A. Risk factors related to sleep bruxism in children: a systematic literature review. Arch Oral Biol. 2015 Nov;60(11):1618-24. http://dx.doi.org/10.1016/j.archoralbio.2015.08.014. PMid:26351743.

8. Gomes MC, Neves ET, Perazzo MF, Souza EGC, Serra-Negra JM, Paiva SM, et al. Evaluation of the association of bruxism, psychosocial and sociodemographic factors in preschoolers. Braz Oral Res. 2018 Feb;32(0):e009. http://dx.doi.org/10.1590/1807-3107bor-2018.vol32.0009. PMid:29412225

9. Ribeiro MB, Manfredini D, Tavares-Silva C, Costa L, Luiz RR, Paiva S, et al. Association of possible sleep bruxism in children with different chronotype profiles and sleep characteristics. Chronobiol Int. 2018 May;35(5):633-42. http://dx.doi.org/10.1080/07420528.2018.1424176. PMid:29363987. 
10. American Academy of Sleep Medicine - AASM. ICSD-2 International Classification of Sleep Disorders: diagnosis and coding manual. 2nd ed. Westchester: AASM; 2005. Sleep related bruxism; p. 189-92.

11. Drumond CL, Paiva SM, Vieira-Andrade RG, Ramos-Jorge J, Ramos-Jorge ML, Provini F, et al. Do family functioning and mothers' and children's stress increase the odds of probable sleep bruxism among schoolchildren? A case control study. Clin Oral Investig. 2020 Feb;24(2):1025-33. http://dx.doi.org/10.1007/s00784-019-02997-8. PMid:31286259.

12. Massignan C, de Alencar NA, Soares JP, Santana CM, Serra-Negra J, Bolan M, et al. Poor sleep quality and prevalence of probable sleep bruxism in primary and mixed dentitions: a cross-sectional study. Sleep Breath. 2019 Sep;23(3):935-41. http://dx.doi.org/10.1007/s11325-018-1771-y. PMid:30569316.

13. Saulue P, Carra MC, Laluque JF, d'Incau E. Comprendre les bruxismes chez l'enfant et l'adolescent. Int Orthod. 2015 Oct;13(4):489. http://dx.doi.org/10.1016/j.ortho.2015.09.002.

14. Manfredini D, Winocur E, Guarda-Nardini L, Paesani D, Lobbezoo F. Epidemiology of bruxism in adults: a systematic reviw of the literature. J Orofac Pain. 2013;27(2):99-110. http://dx.doi.org/10.11607/jop.921. PMid:23630682.

15. Mota-Veloso I, Celeste RK, Fonseca CP, Soares MEC, Marques LS, Ramos-Jorge ML, et al. Effects of attention deficit hyperactivity disorder signs and socio-economic status on sleep bruxism and tooth wear among schoolchildren: structural equation modelling approach. Int J Paediatr Dent. 2017 Nov;27(6):523-31. http://dx.doi.org/10.1111/ipd.12291. PMid:28155241.

16. Serra-Negra JM, Paiva SM, Fulgêncio LB, Chávez BA, Lage CF, Pordeus IA. Environmental factors, sleep duration, and sleep bruxism in brazilian schoolchildren: a case-control study. Sleep Med. 2014 Feb;15(2):236-9. http://dx.doi.org/10.1016/j.sleep.2013.08.797. PMid:24398188.

17. Serra-Negra JM, Ribeiro MB, Prado IM, Paiva SM, Pordeus IA. Association between possible sleep bruxism and sleep characteristics in children. Cranio. 2017 Sep;35(5):315-20. http://dx.doi.org/10.1080/08869634.2016.1239894. PMid:27691903.

18. Prado IM, Abreu LG, Silveira KS, Auad SM, Paiva SM, Manfredini D, et al. Study of associated factors with probable sleep bruxism among adolescents. J Clin Sleep Med. 2018 Aug;14(8):1369-76. http://dx.doi.org/10.5664/jcsm.7276. PMid:30092895.

19. Bartlett D, Ganss C, Lussi A. Basic Erosive Wear Examination (BEWE): a new scoring system for scientific and clinical needs. Clin Oral Investig. 2008 Mar;12(Suppl 1):S65-8. http://dx.doi.org/10.1007/s00784-007-0181-5.

20. Duarte J, Souza JF, Cavalcante-Leão B, Todero SRB, Ferreira FM, Fraiz FC. Association of possible sleep bruxism with daytime oral habits and sleep behavior in schoolchildren. Cranio. 2019 Sep:1-7. http://dx.doi.org/10.1080/08869634.2019.1661113.

21. Olczak-Kowalczyk D, Korporowicz E, Gozdowski D, Lecka-Ambroziak A, Szalecki M. Oral findings in children and adolecents with Prades-Willi syndrome. Clin Oral Investig. 2019 Mar;23(3):1331-9. http://dx.doi.org/10.1007/s00784-018-2559-y. PMid:30006686.

22. Wetselaar P, Manfredini D, Ahlberg J, Johansson A, Aarab G, Papagianni CE, et al. Associations between tooth wear and dental sleep disorders: a narrative overview. J Oral Rehabil. 2019 Aug;46(8):765-75. http://dx.doi.org/10.1111/joor.12807. PMid:31038764.

23. Lavigne GJ, Khoury S, Abe S, Yamaguchi T, Raphael K. Bruxism physiology and pathology: an overview for clinicians. J Oral Rehabil. 2008 Jul;35(7):476-94. http://dx.doi.org/10.1111/j.13652842.2008.01881.x. PMid:18557915.

24. Jernelöv S, Lekander M, Almqvist C, Axelsson J, Larsson H. Development of atopic disease and disturbed sleep in childhood and adolescence--a longitudinal population-based study. Clin Exp Allergy. 2013 May;43(5):552-9. http://dx.doi.org/10.1111/cea.12087. PMid:23600546. 
25. Carra MC, Huynh N, Morton P, Rompré PH, Papadakis A, Remise C, et al. Prevalence and risk factors of sleep bruxism and wake-time tooth clenching in a 7- to 17-yr-old population. Eur J Oral Sci. 2011 Oct;119(5):386-94. http://dx.doi.org/10.1111/j.1600-0722.2011.00846.x. PMid:21896056.

26. Insana SP, Gozal D, McNeil DW, Montgomery-Downs HE. Community based study of sleep bruxism during early childhood. Sleep Med. 2013 Feb;14(2):183-8.

http://dx.doi.org/10.1016/j.sleep.2012.09.027. PMid:23219144.

27. Serra-Negra JM, Paiva SM, Abreu MH, Flores-Mendoza CE, Pordeus IA. Relationship between tasks performed, personality traits, and sleep bruxism in Brazilian school children--a population-based cross-sectional study. PLoS One. 2013 Nov;8(11):e80075.

http://dx.doi.org/10.1371/journal.pone.0080075. PMid:24244614.

\section{CONFLICTS OF INTERESTS}

The authors declare no conflicts of interest.

\section{${ }^{*}$ CORRESPONDING AUTHOR}

Diego Patrik Alves Carneiro, FHO/UNIARARAS - Fundação Hermínio Ometto, Departamento de Ortodontia, Av. Dr. Maximiliano Baruto, 500, Jardim Universitário, 13607-339 Araras - SP, Brasil, e-mail: diegopatrikmoa@gmail.com

Received: June 23, 2020

Accepted: October 2, 2020 